\title{
Spatial Microstructural Ordering of Expansive Clay Minerals
}

\author{
T. López-Lara $\mathbb{D},{ }^{1}$ J. B. Hernández-Zaragoza $\left(\mathbb{D},{ }^{1}\right.$ D. Carreón-Freyre $\mathbb{D}^{2},{ }^{2}$ M. Cerca, ${ }^{2}$ \\ E. Rojas-González, ${ }^{1}$ A. G. Minor Franco, ${ }^{3}$ G. Martínez-Barrera $\mathbb{D}^{1},{ }^{4}$ and R. Salgado-Delgado ${ }^{5}$ \\ ${ }^{1}$ División de Estudios de Posgrado, Facultad de Ingeniería, Universidad Autónoma de Querétaro, Cerro de las Campanas S/N, \\ Col. Las Campanas, 76010 Santiago de Querétaro, QRO, Mexico \\ ${ }^{2}$ Laboratorio de Mecánica Multiescalar de Geosistemas, Centro de Geociencias, Universidad Nacional Autónoma de México, \\ Blvd. Juriquilla 3001, Col. Juriquilla, 76230 Querétaro de Arteaga, QRO, Mexico \\ ${ }^{3}$ Facultad de Ingeniería Civil, Universidad Autónoma de Nuevo León, Avenida Universidad y Fidel Velázquez, \\ Ciudad Universitaria, 66450 San Nicolás de los Garza, NL, Mexico \\ ${ }^{4}$ Laboratorio de Investigación y Desarrollo de Materiales Avanzados (LIDMA), Facultad de Química, \\ Universidad Autónoma del Estado de México, Km 12 de la carretera Toluca-Atlacomulco, \\ San Cayetano 50200, MICH, Mexico \\ ${ }^{5}$ División de Estudios de Posgrado e Investigación, Instituto Tecnológico de Zacatepec, Calzada Tecnológico No. 27, Col. Centro, \\ 62780 Zacatepec, MOR, Mexico
}

Correspondence should be addressed to T. López-Lara; lolte@uaq.mx

Received 1 September 2017; Accepted 26 February 2018; Published 1 April 2018

Academic Editor: Arnaud Perrot

Copyright (C) 2018 T. López-Lara et al. This is an open access article distributed under the Creative Commons Attribution License, which permits unrestricted use, distribution, and reproduction in any medium, provided the original work is properly cited.

\begin{abstract}
The volumetric change within soils containing expanding clays depends upon their spatial ordering and their mineralogy. So this work studies the spatial microstructural ordering and mineralogy of different expanding clays in order to correlate them with some of their geotechnical properties (plasticity, classification, and expansion). The clay microstructure was obtained using X-ray diffraction, and sweeping electronic microscopy. Physical characterization includes $\mathrm{pH}$ analysis. Clays with greater swelling (12.1-14.6\% expansion) present greater agglomeration (gathering) (20-50 microns) in a flocculated structure that mainly contained sodic montmorillonite with $14-22 \AA$ openings and 8.28 average $\mathrm{pH}$, which indicates high electron concentrations with border-face interactions. Clays with the least expansion (7.6\%) present lower agglomerations (5-10 microns) with face-to-face contacts within a dispersed structure that mainly contained calcium montmorillonite with openings lower than $15 \AA$ and $\mathrm{pH} 7.56$, which indicates a low electron concentration and face-to-face interaction. Major clay expansion corresponds to a greater size agglomerates, greater opening between particles, and greater $\mathrm{pH}$ presenting border-face and face-to-face interactions of a flocculent structure. Yet, the soils with lower expansion only present face-to-face interactions corresponding to a dispersed structure.
\end{abstract}

\section{Introduction}

Expanding soils have the tendency to swell or contract in the presence or absence of water. Generally, the expansion capacity of a soil is determined only by carrying out physical properties such as index property essays, expansion percentage, and swelling pressure. Expanding soils owe their behavior to their mineral constituents [1]. This work aims to provide characterization studies for identifying the mineralogy responsible for the expansion and its relation to the spatial order generated.

\section{Previous Work}

Potentially expanding soils may be found anywhere in the world particularly in regions with semiarid climates [1]. Clay minerals are hydrated aluminum silicates classified within the phyllosilicate group with a crystal size smaller than $2 \mu \mathrm{m}$. The characteristic structure of these materials is constituted by two types of layers, linked through oxygen: one formed by tetrahedron and another one formed by octahedron with the thicknesses of $3 \AA$ and $4 \AA$, respectively [2]. 
The center of the tetrahedron is commonly made of $\mathrm{Si}^{4+}$ frequently substituted by $\mathrm{Al}^{3+}$ and sporadically by $\mathrm{Fe}^{3+}$. The center of the octahedron is being occupied by $\mathrm{Al}^{3+}, \mathrm{Mg}^{2+}$, and $\mathrm{Fe}^{2+}$, sometimes by $\mathrm{Fe}^{3+}$ and $\mathrm{Li}^{+}$, amongst others. Clay minerals differ in various types in relation to the number of structure layers according to the ordering grade and type of isomorphic substitutions [3]. Clay classification is based on the tetrahedron (T) and octahedral $(\mathrm{O})$ layers united to form a lattice, $1: 1$ (T-O). One tetrahedron layer united to an octahedron and the other side $2: 1$ (T-O-T) and 2:1:1 (T-O-T-O). Smectites, and in particular their most representative mineral montmorillonite studied in this work, are part of the T-O-T group. Montmorillonite owes its denomination at its finding place Montmorillon, France. It is an aluminum nonsilicate type $2: 1$, which is a compound of an octahedral layer of $\mathrm{Al}_{2} \mathrm{O}_{3}$ located among two tetrahedron layers of $\mathrm{SiO}_{2}$ [4]. Montmorillonite is the most studied clay material [2], which layers have permanent negative charges due to the isomorphic substitutions and $\mathrm{pH}$ depending on the charges that they develop within the superficial border hydroxyl [5]. Montmorillonites are not electrically neutral, and the isomorphic substitution is the cause of the electric charge in the lattice. They are found to be separated by weakly hydrated cations $\left(\mathrm{Ca}^{2+}, \mathrm{Mg}^{2+}, \mathrm{Na}^{+}\right.$, and $\mathrm{K}^{+}$). This charge favors the penetration of fluids increasing the interlaminate distance, called crystal swelling [6].

Another property consists in the cationic interchange capacity (CIC) [7], which is the sum of all the exchangeable cations a material can absorb at a certain $\mathrm{pH}$. The total addition of the electric decompensations in the particle translates into the surface formation of the double-diffused electric layer composed by a negative layer located on the surface of the particle, surrounded by an exterior layer of opposite charge compensating electrically the first layer. The negative sign will always be in the particle's face and the positive sign in the exterior layer. Within the particle's edges, the charge sign depends on the intermediate $\mathrm{pH}$. Hence, for an acid and neutral $\mathrm{pH}$, the charge in the border is positive, and for a greater $\mathrm{pH}$ (medium alkaline), the electric charge of the border shall be negative. For such reason, an increase in the salt concentration of the fluid implies a decrease of the thickness of the double electric diffused layer; hence, the characteristics of such double layer allow the particles to associate (floculation) or remain isolated up to their sedimentation (dispersion) [6]. Floculation can be given by means of (1) edge-edge contact, where the particles unite through electrostatic forces among the edges of opposite charges, (2) face-edge contacts are contacts between edges with positive charge and faces of negative charge, and (3) face-to-face contacts, when the solution presents very low electrolyte concentration [6]. The negative charge is the primary factor in the clay dispersion, and the $\mathrm{pH}$ affects clay dispersion through charge changes upon the clay particles. An increase in the negative charge is also positively correlated with $\mathrm{pH}$. Nonetheless, the pending of these relations varies between the soil's clays. When comparing the mineral values of the pure clay, quoted within the soil's literature that classifies similar mineralogy, it is found that the soil's clays present greater flocculation values [8]. The identification and quantification of the clay minerals is important, in particular the ones responsible for the susceptibility of the soils to produce expansion and contraction of such soils, such as smectites (saponite), montmorillonite, nontronite, hectorite, and beidelite $[3,9]$. The volume change capacity of these soils is conditioned by the clay content and its mineralogy [2]. For identifying the mineral contents within clay, the most often used methods are X-ray diffraction and electronic microscopy [10]. Characterization spectroscopy of the clay minerals, such as montmorillonite and caolin, was made in the wavelength region 2.5 to 14 micrometers; in relation to characteristics such as absorption and its clay mineral mixture, changes were investigated [9]. Laser fluorescence spectroscopy resolved through time, and the long X-ray absorption of the fine structure has been used to identify lantinids and trivalent actinides in different montmorillonites and illites [11]. Image processing and measuring geometric methods were introduced to quantify microporosity at multiple scales of soil images. Information software about the basis of these methods was used to quantify the scanning electron microscopy of clay samples during the cut essay [12]. The expansion potential evaluation was carried out by means of index testing (Atterberg limits, lineal contraction, free expansion, solid content, volume change potential, and clay activity). The relation between the expansion potential and plasticity index of the clays was proposed by Holtz and Gibbs [13]. The clay activity is defined as the relation between the plasticity index and the particle percentage lower than $2 \mu \mathrm{m}$ [14]. In order to estimate the free expansion, a cylindrical probe, with known soil volume (dry), is submerged in water without any overcharge application while the expansion is given. The difference between the final and the initial volume expressed as initial volume percentage is the free expansion [15]. It has been demonstrated that the expansion-contraction testing is a simple and economic means to evaluate the soil's expansiveness [16]. Even though the evaluation of the expanding clays potential has been the object of intense investigation during the last 40 years, its treatment in the geotechnical usual practice throughout the world continues being uneven [16]. The expansion characteristics of the expanding soil samples reinforced and remolded with different fiber contents and the aspect relationship were studied by means of oedometric testing of monodimensional consolidation of contraction and expansion. The vertical oscillation reduction and expansion pressure was the maximum at low-volume relations in the different fiber contents [17]. So adding mineral characterization of soils, this work studies the spatial microstructural ordering of different expanding clays in order to correlate them with some of their geotechnical properties (plasticity, classification, and expansion). The clay microstructure was obtained using X-ray diffraction and sweeping electronic microscopy.

\section{Experimental Methodology}

3.1. Soil Sampling. Jurica village located in the state of Querétaro, Mexico, was selected as study area because of the presence of expanding soils that have caused severe damages documented elsewhere [18].

We also worked with the expanding soils of "Seis de Marzo" village $\left(25^{\circ} 40^{\prime}\right.$ lat, $100^{\circ} 15^{\prime}$ long) nearby the Santa Catarina River in Monterrey, Nuevo León, Mexico.

Nonaltered samples were collected by digging an open pit well (JUQ01 and JUQ02; $20^{\circ} 40.6^{\prime}$ lat, $100^{\circ} 27.3^{\prime}$ long) at 
TABle 1: Soil analysis using X-ray diffraction.

\begin{tabular}{llccc}
\hline Soil & Mineral predominant clay & Opening interlaminate $\left(\AA=1 \times 10^{-7} \mathrm{~mm}\right)$ & Opening quartz $(\AA)$ & Diffractogram \\
\hline JUQ01 & Sodic montmorillonite, quartz & 14 to 18 & 3.34 & Figure 1 \\
JUQ02 & Sodic montmorillonite, quartz & 18 to 22 & 3.34 & Figure 2 \\
JAV & Sodic montmorillonite, quartz & 18 to 22 & 3.34 & Figure 3 \\
SDM & Calcic montmorillonite, quartz & Up to 15 & 3.34 & Figure 4 \\
\hline
\end{tabular}

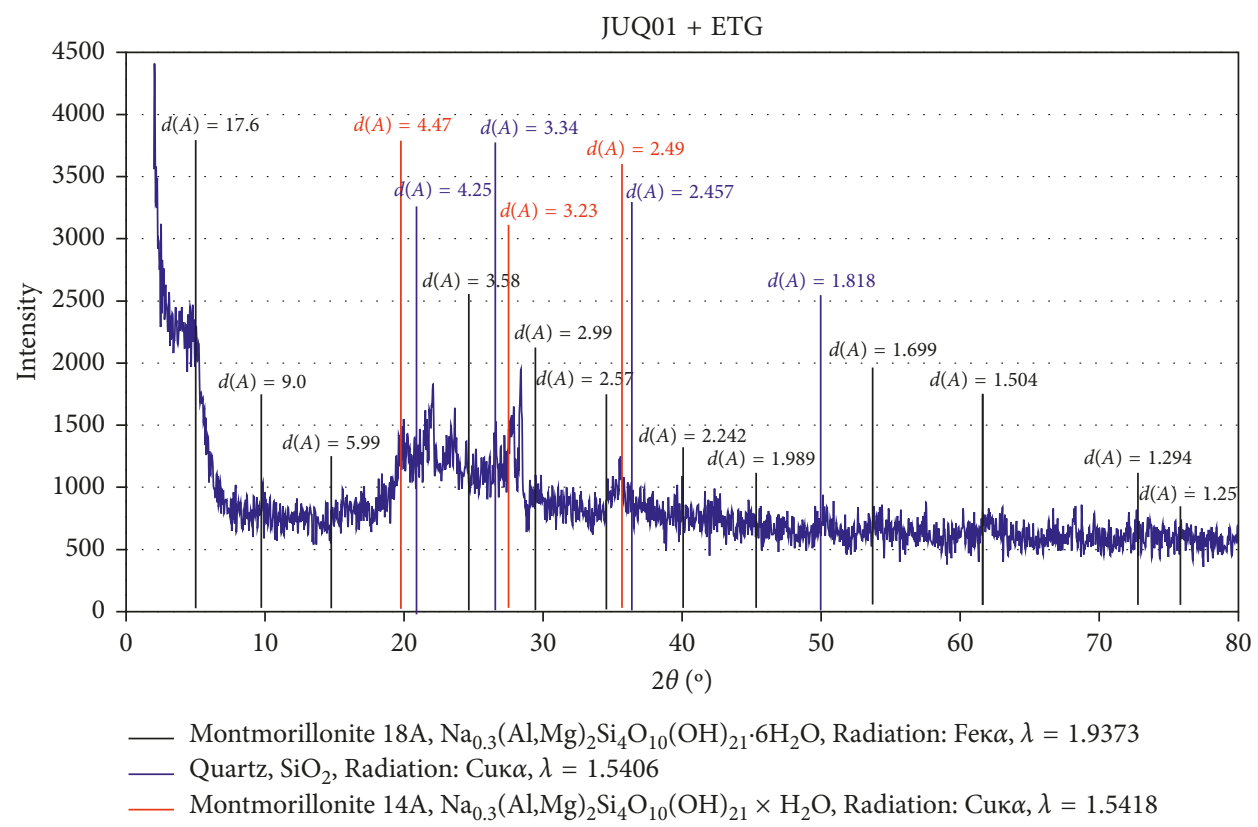

Figure 1: Soil diffractogram: Jurica, Querétaro, México (JUQ01) + ethylene-glycol.

0.50 and $1.00 \mathrm{~m}$ depth; respectively, and an additional sample in Jardines del Valle village (JAV; $20^{\circ} 37^{\prime}$ lat, $100^{\circ} 27^{\prime}$ long) (called) in as far as Querétaro is referred.

\subsection{Physical and Chemical Characterization of Soil}

3.2.1. Sample Preparation for X-Ray Diffraction and Scanning Electron Microscopy. The analysis was carried out using a RIGAKU model Dmax 2100 powder-type X-ray diffractometer and a scanning electron microscopy PHILIPS XL30 ESEM microscope. First, samples were oven dried for 24 hours and later filtered through a sieving mesh no. $250(58 \mu \mathrm{m})$, for the corresponding X-ray diffractometry and electronic probe microscope. Adding ethylene-glycol during sample preparation for later placement within the X-ray diffractometer does not inhibit the clay's expansion [19] but eliminates organic matter in order to obtain a clearer diffractometry. The result is presented as a diffractogram that is a plot of the $2 \theta$ (incidence angle between the Röntgen beam ray at the exit and the receptor) versus its intensity. For the probe analysis, the sieved sample was placed on an adhesive band. The sample was placed in a sample carrier and mounted on the microscope for the analysis.

3.2.2. Determining the Mineralogy and Its Morphology. The mineralogy of the clays was determined with the use of X-ray diffractometry and electronic sweep microscopy. The minerals were identified by the use of diffractograms.

\subsection{Geotechnical Soil Characterization}

3.3.1. Atterberg Limits (Consistency), Classification, and Soil Expansion. Plasticity of clays is commonly expressed in terms of the Atterberg limits which measure humidity [20] for which clayey soils change behavior. The procedure is a standard soil mechanics laboratory test yielding the different limits: contraction limit [21], liquid limit, plastic limit, and plastic index [22]. The soil classification was conducted according to the united soil classification system. The expansion was measured with an odometer in an unloaded free form; the test consisted in carving a nonaltered sample in a test ring allowing drainage on both faces, and then placing the ring and the sample in the odometers and saturating. The initial and final height of the sample is measured for obtaining an expansion percentage [23].

3.4. $\mathrm{pH}$ Analysis. The $\mathrm{pH}$ indicates the relative ion quantities $\mathrm{H}^{+}$and $\mathrm{OH}^{-}$that the solution contains and reflects the base saturation percentage. The soil $\mathrm{pH}$ characteristic values range from 4 to 10 . If $\mathrm{pH}$ is higher than 8.5 , the soil would possibly contain an excess in sodium. Generally, a lower calcium quantity corresponds to a lower $\mathrm{pH}$ value; therefore, to correct 


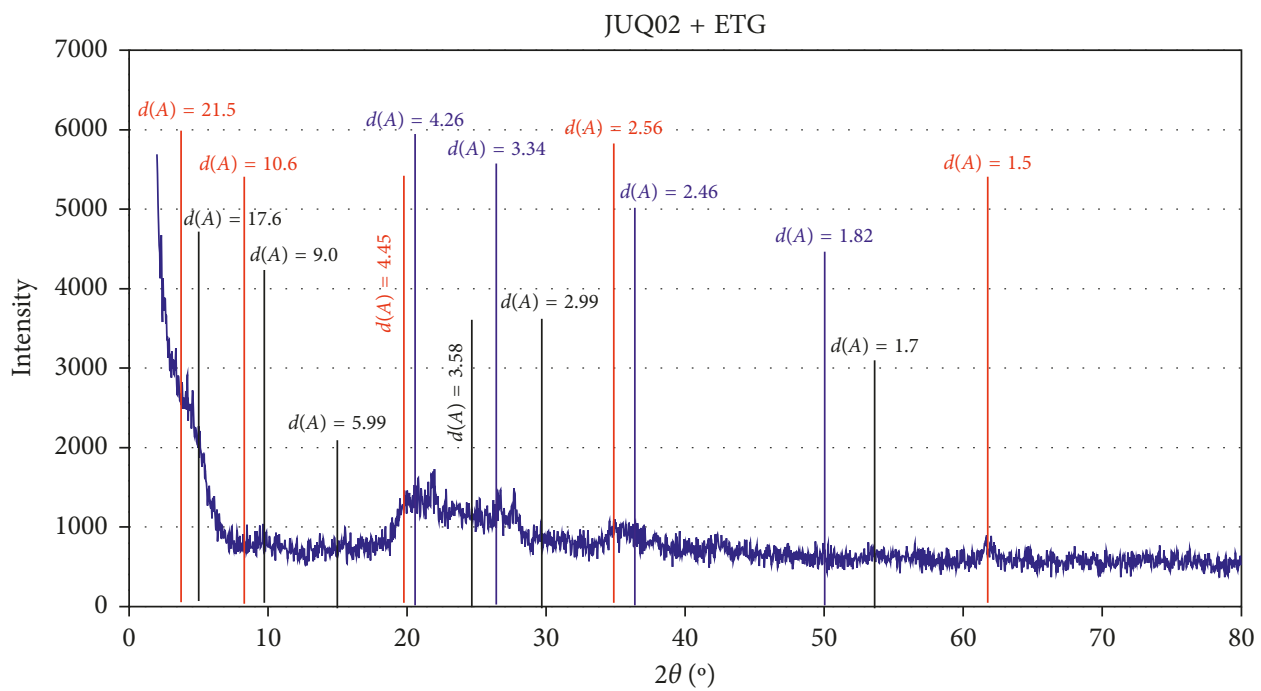

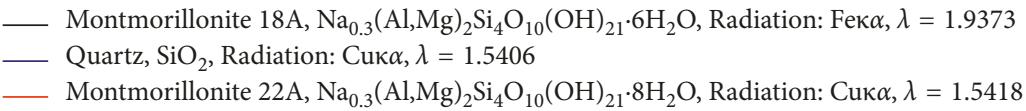

FIgure 2: Soil diffractogram: Juríca, Querétaro, México (JUQ02) + ethylene-glycol.

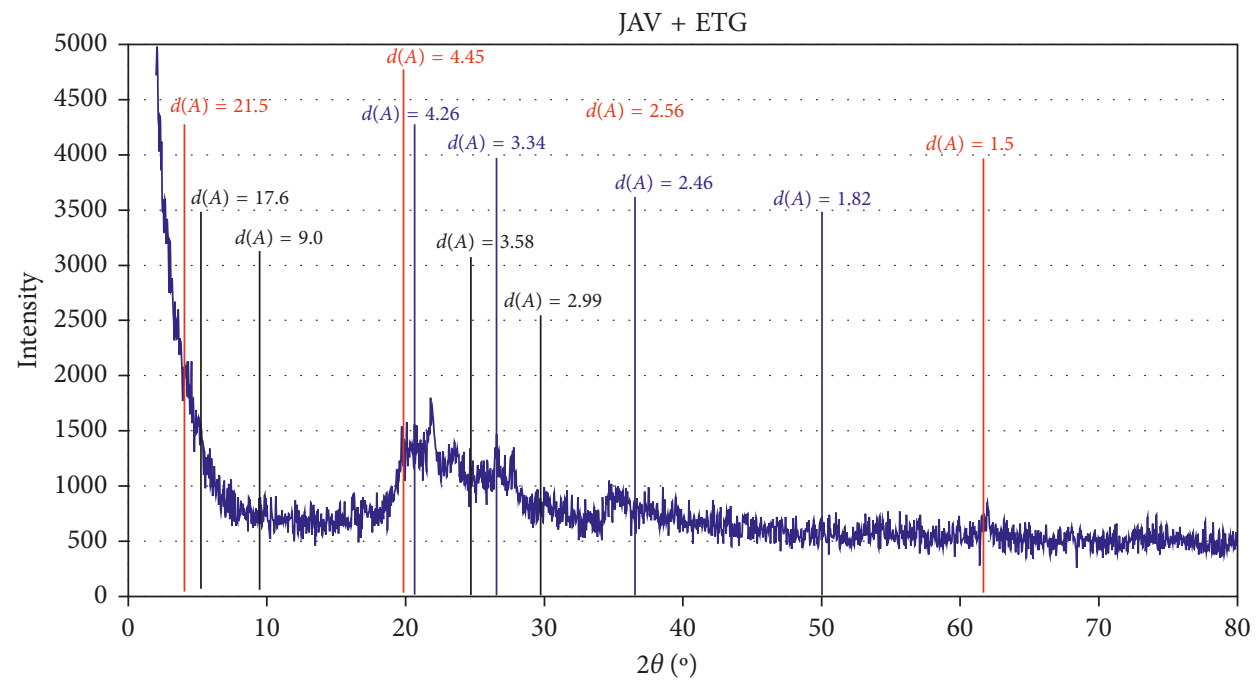

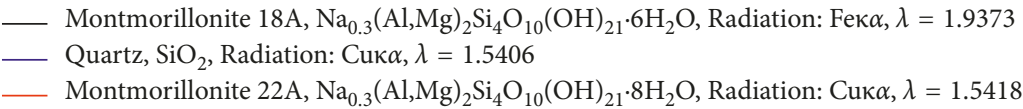

FIgure 3: Soil diffractogram: Jardines del Valle, Querétaro, México (JAV) + ethylene-glycol.

the excessive acidity, calcium in quicklime is added. Soil $\mathrm{pH}$ is important for cation exchange capacity (CEC) because as $\mathrm{pH}$ increases (becomes less acidic), the number of negative charges on the colloids increases, thereby increasing CEC. Cations are held by negatively charged particles of clay called colloids. Colloids consist of thin, flat plates, and for their size, they have a comparatively large surface area. For this reason they are capable of holding enormous quantities of cations [24].

Determining the sample $\mathrm{pH}$ was conducted with a $\mathrm{pH}$ apparatus model Hanna Instruments-ph-211 calibrated with a buffer solution $\mathrm{pH}$ 7.0 Merck KGaA. The $\mathrm{pH}$ of the distilled water used was 7.0.

\section{Results}

\subsection{Physical and Chemical Clay Characterization}

4.1.1. X-Ray Diffraction Powder Method. The diffractograms showed that a mineralogy constituted mainly of phyllosilicates specifically montmorillonite, with a signature of quartz as shown in Table 1, along with the interlayer opening (the distance between the clay laminations). The diffractograms are exhibited from Figures 1-4.

Intensities indicate the relative presence of the different mineral phases allowing observation which predominates 


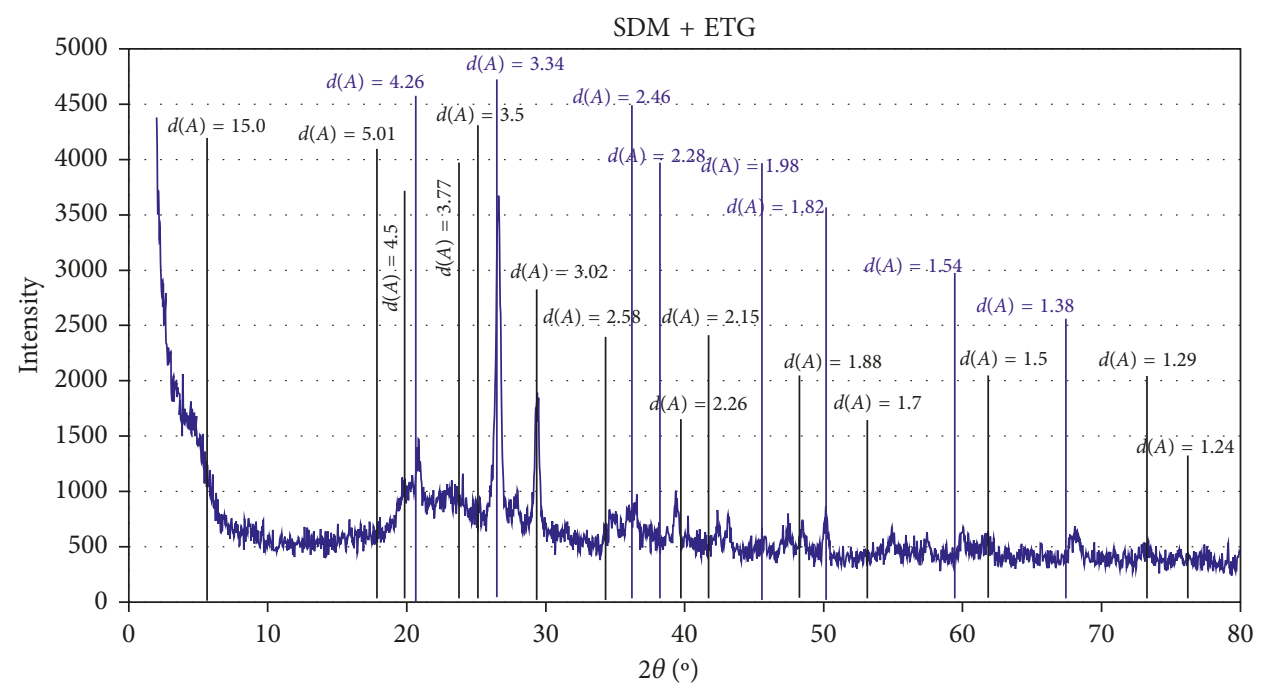

- Montmorillonite $15 \mathrm{~A}, \mathrm{Ca}_{0.2}(\mathrm{Al}, \mathrm{Mg})_{2} \mathrm{Si}_{4} \mathrm{O}_{10}(\mathrm{OH})_{21} \cdot 4 \mathrm{H}_{2} \mathrm{O}$, Radiation: $\mathrm{Cu \kappa} \alpha, \lambda=1.5406$

- Quartz, $\mathrm{SiO}_{2}$, Radiation: Cuk $\alpha, \lambda=1.5406$

Figure 4: Soil diffractogram: Monterrey, Nuevo León, México (SDM) + ethylene-glycol.

TABle 2: Analysis results through the scanning electron microscopy.

\begin{tabular}{lccc}
\hline Soil & Approach & Type and particle size $(\mu \mathrm{m})$ & Structure type \\
\hline JUQ01 & $2000 \mathrm{x}$ & Agglomerations: 20 and 1 to 2.5 laminates & $\begin{array}{c}\text { Flocculated (face-to-face) } \\
\text { Flocculated (edge-face) }\end{array}$ \\
JUQ02 & $6000 \mathrm{x}$ & Laminate agglomeration: 50 & Flocculated (face-to-face) \\
& $2000 \mathrm{x}$ & Laminate agglomeration: 20 & Flocculated (face-to-face) \\
JAV & $6000 \mathrm{x}$ & 1 to 2 spheres & Flocculated (sphere) \\
& $2000 \mathrm{x}$ & Agglomeration 5 to 10 & Disperse (face-to-face) 7 \\
SDM & $6000 \mathrm{x}$ & 1 to 2 spheres & Disperse (sphere) \\
\end{tabular}

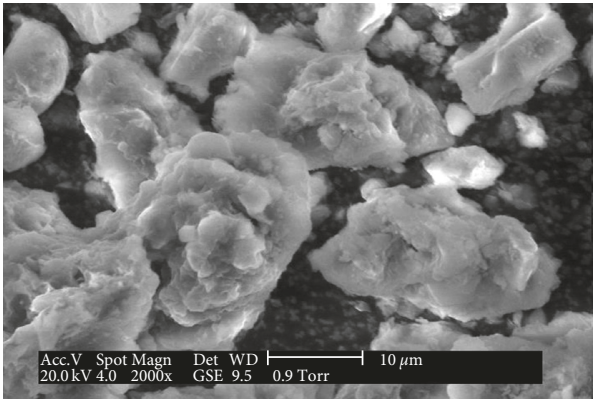

FIgURE 5: Soil micrographs: Juríca, Querétaro, México (JUQ01) with a 2000x (left) and 6000x (right) approach.

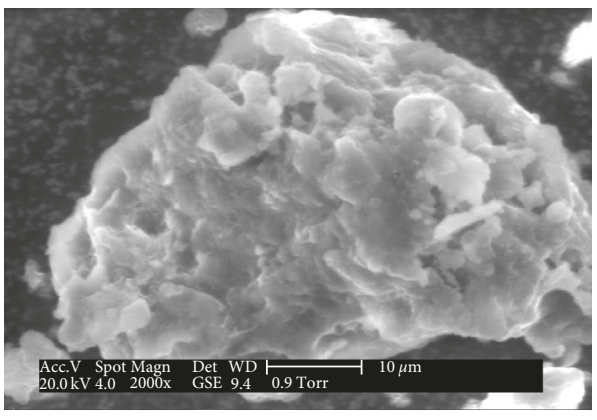

FIgURE 6: Soil micrographs: Juríca, Querétaro, México (JUQ02) with a 2000x (left) and 6000x (right) approach.

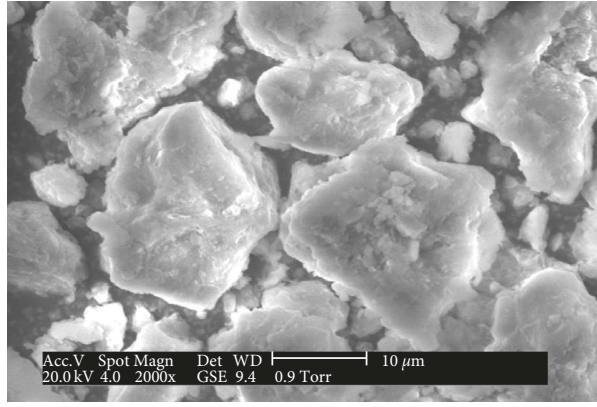

Figure 7: Soil micrographs: Jardines del Valle, Querétaro, México (JAV) with a 2000x (left) and 6000x (right) approach.

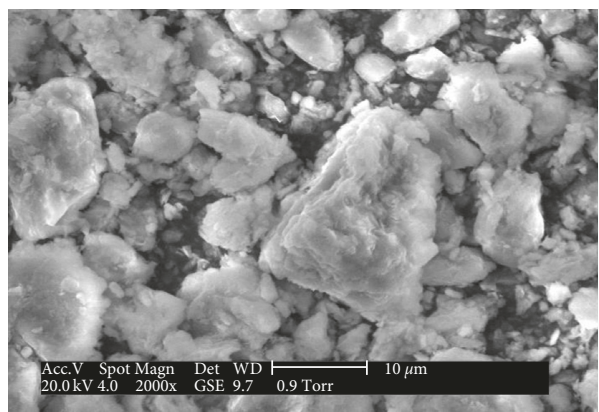

Figure 8: Soil micrographs: Monterrey, Nuevo León, México (SDM) with a 2000x (left) and 6000x (right) approach. 
TABLE 3: Geotechnical soil characterization of the studied soils.

\begin{tabular}{|c|c|c|c|c|c|c|c|c|c|}
\hline Soil & $\begin{array}{l}\text { Liquid limit } \\
\text { (\%) }\end{array}$ & $\begin{array}{c}\text { Plastic limit } \\
(\%)\end{array}$ & $\begin{array}{l}\text { Plastic Index } \\
\text { (\%) }\end{array}$ & $\begin{array}{c}\text { Contraction limit } \\
(\%)\end{array}$ & Specific gravity & $\begin{array}{l}\text { Volumet } \\
\left(\mathrm{Kg} / \mathrm{m}^{3}\right)\end{array}$ & $\begin{array}{l}\text { ric weight } \\
\left(\mathrm{KN} / \mathrm{m}^{3}\right)\end{array}$ & Expansion (\%) & $\begin{array}{c}\text { Classification } \\
\text { USCS }\end{array}$ \\
\hline JUQ01 & 59.7 & 21.0 & 38.7 & 12.5 & 2.61 & 1,730 & 16.97 & 14.6 & $\mathrm{CH}$ \\
\hline JUQ02 & 61.2 & 22.8 & 38.4 & 12.7 & 2.62 & 1,700 & 16.67 & 14.1 & $\mathrm{CH}$ \\
\hline JAV & 81.8 & 30.0 & 51.8 & 16.5 & 2.54 & 1,680 & 16.48 & 12.1 & $\mathrm{CH}$ \\
\hline SDM & 57.6 & 24.4 & 33.2 & 13.4 & 2.59 & 1,660 & 16.28 & 7.6 & $\mathrm{CH}$ \\
\hline
\end{tabular}

TABLE 4: Results of the pH of the studied soils.

\begin{tabular}{lccc}
\hline Soil & $\mathrm{pH}$ & Thompson scale (Thompson, 1978) & $\mathrm{T}\left({ }^{\circ} \mathrm{C}\right)$ \\
\hline JUQ01 & 8.05 & Medium alkalinity & 21.5 \\
JUQ02 & 8.41 & Medium alkalinity & 22.5 \\
JAV & 8.38 & Medium alkalinity & 22.6 \\
SDM & 7.56 & Weak alkalinity & 22.5 \\
\hline
\end{tabular}

within the analyzed samples. The transcendence that the separations have at $\AA$ in each type of mineral gives us an idea of their expanding capacity. SDM soil had lower interlayer opening, lower intensity, and thus less expansion.

4.1.2. Scanning Electron Microscopy (SEM). The scanning electron microscopy results show the ordering or spatial disposition of the particles of the studied soils. Irregular morphologies and clay lamination sizes observed are shown in Table 2 and Figures 5-8.

Figures 5 and 6 (same soil JUQ-QRO) and Figure 7 (JAVQRO) show spongy lumps of sizes $20-50 \mu \mathrm{m}$ (flocculated structure) that are formed of flattened particles corresponding to the forms of montmorillonite mineral. These three soils showed greater expansion. In contrast, Figure 8 shows spongy lumps smaller $(5-10 \mu \mathrm{m})$ but now with dispersed structure formed by of flattened particles corresponding to the forms of montmorillonite mineral. This soil showed lower expansion due to the difference of the mineral montmorillonite (calcic).

In general, all of the micrographs exhibit the fact that the clays present in a laminate form overlapping layers one against the other, forming agglomerations and having small particles of sphere aggregates, such being the case of Jardines del Valle (JAV), Monterrey, N. L. (SDM).

4.2. Geotechnical Soil Characterization. Selected geotechnical characteristics measured in the studied soils are presented in Table 3 including their indices properties, liquid limit, plastic limit and plastic index [22], and contraction limit [21], as well as its specific gravity [25], volumetric weight [26], expansion [23], and classification according to the Unified Soil Classification System (USCS). All the studied soils were classified as high plasticity clays $(\mathrm{CH})$. Adding, the maximum dry volumetric weight was $1400 \mathrm{~kg} / \mathrm{m}^{3}$ and the optimum humidity measured was $28.7 \%$.

4.3. Hydrogen Potential $(\mathrm{pH})$. The $\mathrm{pH}$ results and the ambient temperature at the time when the measurements were taken are shown in Table 4. Based upon the Thompson scale (Thompson, 1978), the $\mathrm{pH}$ values are high (alkaline soils) and also the X-ray diffraction results yielded high values in sodic quantities in the Jurica and Jardines del Valle (JUQ01, JUQ02 \& JAV); hence, its expansion is also greater [27], which corresponds with the results of Table 3 .

\section{Conclusions}

The results allowed (mineralogy composition and micro spatial ordering) explaining and interpreting the principal geotechnical properties of the clay soils. Main properties associated with the soils considered as "expansive soils" are originated by their mineralogy origin, structure, or morphology. Even though they could be apparently identical soils (according to United Classifying Soil System and visualization), they have a completely different mineral content; hence, their behavior is contrasting.

Both soils (Jurica and Jardines del Valle) exhibit sodic montmorillonite reflections (14 to $22 \AA$ ). Monterrey soil presents smaller openings $(15 \AA)$. Although clayish calcic-type montmorillonite predominates the expansion, the percentage is lower in the Monterrey soil, which suggests that calcium soil has a lower alkalinity and interchange capacity of ions and anions (expanding capacity) than the sodic soil. There might be a relationship between the expansion percentage and the predominant clayish mineral contents and its opening. In other words, Querétaro's soils contain sodic montmorillonite clay with greater openings between minerals and so major expansions in comparison to Monterrey's soils bearing calcic montmorillonite.

The microphotographs play a fundamental role to understand the spatial ordering of the studied soils. In the case of Jurica's microphotographs, the overlain laminate cumulus is connected to others forming flocculus in a relation between face-to-face and edge-face. The analysis of all the microphotographs shows agglomeration traces at the rate of $20 \mu \mathrm{m}$ to $50 \mu \mathrm{m}$ by laminated structure overlaid between each other. Queretaro soils showed greater agglomerates with flocculated structure, yet Monterrey's samples attained lower agglomerates with dispersed structure.

A greater specific surface results in greater expansion. As a result, Querétaro's soils exhibit a $14.6 \%$ of expansion; whereas the Monterrey soils with a small specific surface have a smaller expansion of $7.6 \%$.

In suspensions with high electron concentrations, where the $\mathrm{pH}$ is relatively high $(>8.2)$, the face-edge interactions dominate; thus, the positive charge is in the edges and the negative charge in the clay's surface. Querétaro's clays present such flocculation state, for their soils yielded an $8.28 \mathrm{pH}$ average value. A lower electrolyte concentration was found in the case of Monterrey's clay, 7.56. Sodium montmorillonites (Queretaro's clays) are more basic that the calcium 
montmorillonites (Monterrey's clays). Expansive montmorillonites exhibit a greater sodium quantity and higher $\mathrm{pH}$ (alkaline soil).

\section{Conflicts of Interest}

The authors declare that there are no conflicts of interest regarding the publication of this paper.

\section{References}

[1] F. H. Chen, Foundation on Expansive Soil, Elsevier Scientific Company, New York, NY, USA, 1975.

[2] B. Velde, Origin and Mineralogy of Clays, Springer-Verlag, New York, NY, USA, 1995.

[3] H. H. Murray, Applied Clay Mineralogy: Occurrences, Processing and Application of Kaolins, Bentonites, PalygorskiteSepiolite, and Common Clays, Elsevier, London, UK, 2007.

[4] J. Reyes, H. Escalante, and G. Neira, Arcillas Colombianas Tipo Montmrillonita Modificada Dodecil-Sulfato de Sodio Para la Absorción de Cationes Ni2+: Revista ION, Universidad Industrial de Santander, España, 2006.

[5] E. Tombacz and M. Szekeres, "Colloidal behavior of aqueous montmorillonite suspensions: the specific role of $\mathrm{pH}$ in the presence of indifferent electrolytes," Applied Clay Science, vol. 27, no. 1-2, pp. 75-94, 2004.

[6] C. De Santiago Buey, Las Arcillas Magnésicas de la Cuenca del Tajo: Caracterización y Propiedades, Congreso Geologico de España, España, 1997.

[7] A. Betejtin, Curso de Mineralogía, Editorial MIR, Moscú, 1970.

[8] M. Chorom, "Behavior of alkaline sodic soils and clays as influenced by $\mathrm{pH}$ and particle change," Thesis, Department of Soil Science, University of Adelaide, Adelaide, SA, Australia, 1996.

[9] F. A. Yitagetsu, F. van der Meer, H. van der Werff, and C. Hecker, "Spectral characteristics of clay minerals in the 2.5-14 $\mu \mathrm{m}$ wavelength region," Applied Clay Science, vol. 53, no. 4, pp. 581-591, 2011.

[10] G. de Vallejo and I. Luis, Ingeniería Geológica, Prentice-Hall, España, 2004.

[11] E. Hartmann, B. Brendebach, R. Polly, H. Geckeis, and T. Stumpf, "Characterization and quantification of Sm(III)/ad $\mathrm{Cm}$ (III)/clay mineral outer-sphere species by TRLFS in D2O and EXAFS Studies," Journal of Colloid and Interface Science, vol. 353 , no. 2 , pp. 562-568, 2011.

[12] C. Liu, B. Shi, Z. Jian, and C. Tang, "Quantification and characterization of microporosity by image processing, geometric measurement and statistical methods: application on SEM images of clay materials," Applied Caly Science, vol. 54, no. 1, pp. 97-106, 2011.

[13] W. G. Holtz and H. J. Gibbs, "Engineering properties of expansive clays," in Proceeding of the ASCE, Ministry of Agriculture, Government Printery, Port of Spain, Spain, 1956.

[14] J. D. Nelson and D. J. Miller, Expansive Soils, Problems and Practice in Foundation and Pavement Engineering, John Wiley and Sons, Inc., New York, NY, USA, 1992.

[15] W. Lambe, Soil Testing for Engineers, John Wiley and Sons, Inc., New York, NY, USA, 1951.

[16] S. G. Fityus, D. A. Cameron, and P. F. Walsh, "The shrink swell test," Geotechnical Testing Journal, vol. 28, no. 1, pp. 92-101, 2011.

[17] B. V. S. Viswanadham, B. R. Phanikumar, and R. V. Mukherjee, "Swelling behaviour of a geofiber-reinforced expansive soil," Geotextiles and Geomembranes, vol. 27, no. 1, pp. 73-76, 2009.
[18] T. López-Lara, J. B. Hernandez-Zaragoza, and C. Lopez-Cajun, "Mineralogical characterization of stabilized soils," Electronic Journal Geotechnical Engineering, vol. 9, 2004.

[19] J. B. Dixon and S. B. Weed, SSSA: Minerals in Soil Environments, Book Series 1, Soil Science Society of American Madison Wisconsin, Madison, WI, USA, 1989.

[20] ASTM D-2216, Standard Test Methods for Laboratory Determination of Water (Moisture) Content of Soil and Rock by Mass, ASTM, West Conshohocken, PA, USA, 2010.

[21] ASTM D-427, Test Methods for Shrinkage Factors of Soil by the Mercury Method, ASTM, West Conshohocken, PA, USA, 2004.

[22] ASTM D-4318, Standard Test Methods for Liquid Limit, Plastic Limit, and Plasticity Index of Soils, ASTM, West Conshohocken, PA, USA, 2010.

[23] ASTM D-4546, Standard Test Methods for One-Dimensional Swell or Collapse of Cohesive Soils, ASTM, West Conshohocken, PA, USA, 2008.

[24] P. A. Hazelton and B. W. Murphy, Interpreting Soil Test Results: What Do All the Numbers Mean?, CSIRO Publishing, Melbourne, VIC, Australia, 2007.

[25] ASTM D-854, Standard Test Methods for Specific Gravity of Soil Solids by Water Pycnometer, ASTM, West Conshohocken, PA, USA, 2010.

[26] ASTM D-4531-6, Standard Test Methods for Bulk Density of Peat and Peat Products, ASTM, West Conshohocken, PA, USA, 2008.

[27] L. M. Thompson, "El Suelo y su Fertilidad," Editorial Reverts, S.A., España, 1978. 


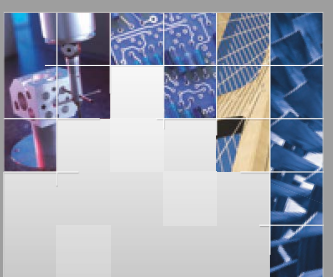

\section{Enfincering}
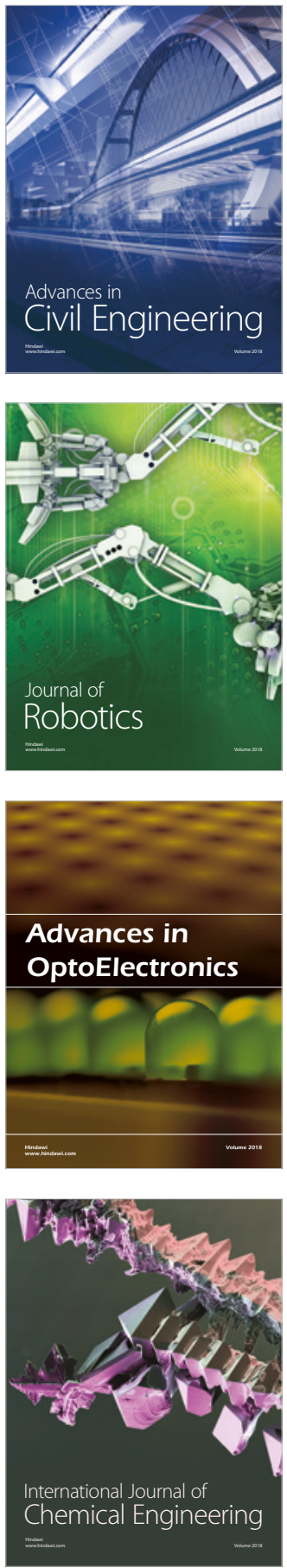

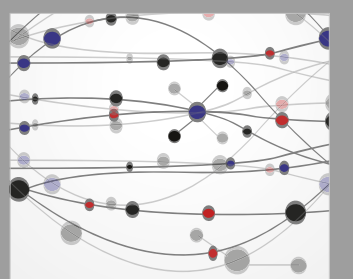

\section{Rotating \\ Machinery}

The Scientific World Journal

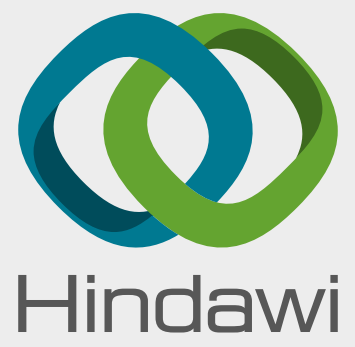

Submit your manuscripts at

www.hindawi.com
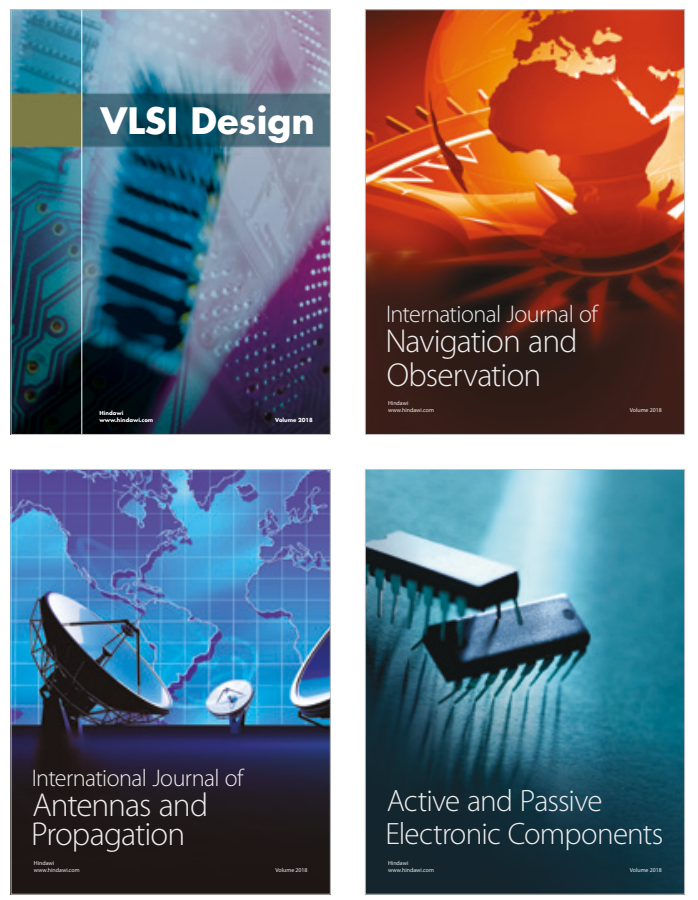
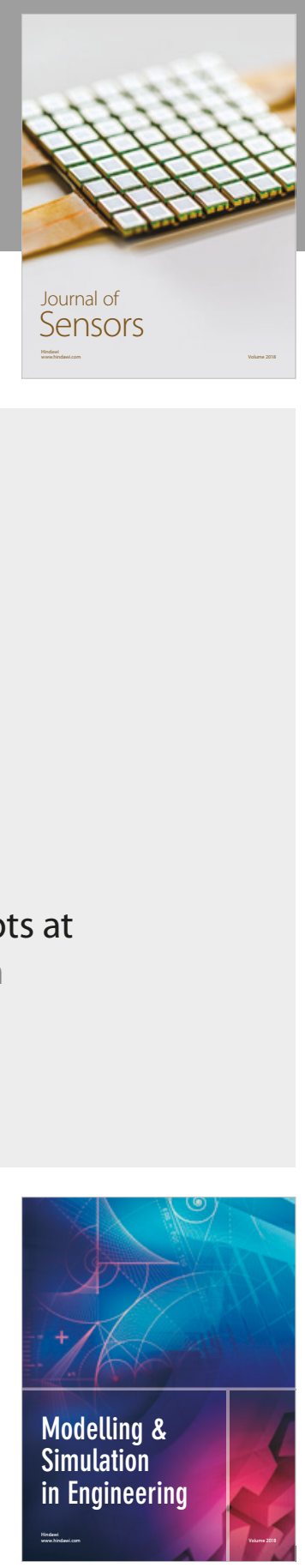

\section{Advances \\ Multimedia}
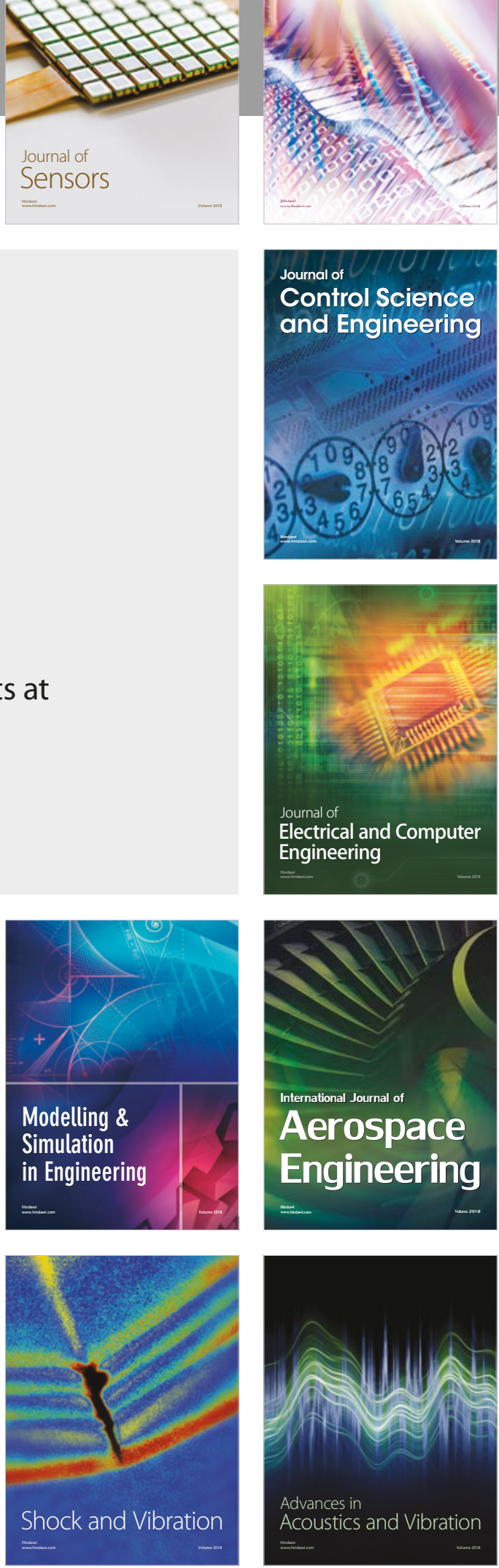